\title{
PENCEGAHAN FRAUD PADA MANTRI PT BANK RAKYAT INDONESIA (PERSERO) TBK KANTOR CABANG GOMBONG: PERAN PENGENDALIAN INTERNAL, KESESUAIAN KOMPENSASI, DAN BUDAYA ETIS ORGANISASI
}

\author{
Triwahyuni, Anton Prasetyo \\ Universitas Putra Bangsa Kebumen \\ antonprasetyo0811@gmail.com
}

\begin{abstract}
Abstrak : Tujuan penelitian ini yaitu menganalisis apakah variable-variabel independen dalam penelitian ini memiliki pengaruh pada pencegahan fraud. Sampel dari penelitian ini adalah Mantri Bank BRI Cabang Gombong dengan masa kerja minimal satu tahun sebanyak 96 responden dengan menggunakan kuesioner. Penentuan sampel yaitudengan teknik nonprobability sampling dan sampel jenuh. Analisis data dengaan menggunakan SPSS 22 for windows yang meliputi uji instrumen validitas dan reliabilitas, uji asumsi klasik dan uji regresi berganda. Dalam penelitian ini diperoleh hasil pengendalian internal, kesesuaian kompensasi dan budaya etis organisasi berpengaruh positif dan signifikan pada pencegahan fraud secara parsial maupun simultan.
\end{abstract}

Kata kunci: pegendalian internal, kesesuaian kompensasi, budaya etis organisasi, pencegahan fraud

\section{PENDAHULUAN}

Kecurangan (fraud) merupakan dampak merugikan yang diakibatkan oleh suatu tindakan sengaja maupun tidak disengaja yang melanggar ketentuanketentuan internal dari sebuah perusahaan yang mencakup sistem, kebijakan, ataupun prosedur. (Jaya, 2017). Berdasarkan penjelasan dari Black's Law Dictionary, fraud merupakan suatu tindakan baik pikiran maupun usaha dengan cara-cara yang tidak benar, seperti tindakan paksa untuk membenarkan diri sendiri serta tindakan-tindakan yang tidak bisa diduga yang tersembunyi, curang, ataupun hal-hal yang tidak jujur yang menyebabkan kerugian pada orang lain sebagai suatu upaya untuk mendapatkan keuntungan pribadi. Fraud dapat dilakukan oleh berbagai pihak seperti pihak manajemen (manajement fraud), pihak karyawan (employee fraud) bahkan fraud dapat dilakukan oleh pihak pelanggan (customer fraud). Tindakan fraud juga terjadi pada berbagai sektor, salah satunya sektor lembaga keuangan.

Berdasarkan Survey ACFE (Association of Certified Fraud Examiner) tentang kecurangan (fraud) yang dilakukan di Indonesia (2019), responden menyatakan bahwa pelaku fraud terbesar ada di kalangan karyawan yaitu sebesar 31,80\%, masa kerja pelaku fraud paling tinggi yaitu antara 6 sampai 10 tahun sebesar 38\% dan jika ditinjau dari tingkat pendidikan pelaku fraud paling banyak memiliki jenjang pendidikan Sarjana dengan prosentase sebesar 73,20\%. Selain itu, hasil survey ini juga menyatakan bahwa secara umum fraud dilakukan oleh laki - laki dengan prosentase $92 \%$ dan rata - rata usia pelaku fraud masuk dalam kategori usia produktif yang berkisar antara 36 sampai 45 tahun sebesar $42 \%$. Selanjutnya, industri keuangan dan perbankan menduduki peringkat pertama sebagai jenis industri yang paling dirugikan oleh fraud sebanyak 41,4\%. Hal ini menggambarkan tingginya fraud pada industri keuangan dan perbankan. 
Paling sedikit strategi anti fraud memiliki empat cara utama yaitu melalui pencegahan terjadinya fraud; mendeteksi kemungkinan terjadinya fraud di setiap bagian yang rawan; melakukan investigasi dan laporan, serta memberikan sanksi kepada orang yang melakukan fraud; dan melakukan tindakan pemantauan, evaluasi dan tindak lanjut (Peraturan Otoritas Jasa Keuangan No. 39/PJOK.03/2019). Hal ini dikarenakan Tingginya potensi fraud dalam industri keuangan dan perbankan.

Upaya pencegahan merupakan usaha awal dalam mencegah serta menekan potensi adanya tindakan fraud yang meliputi fraud awaresess, mengidentifikasi adanya kerawanan, serta mengenali karyawan (know your employee). Kebijakan mengenali karyawan merupakan tindakan dalam mencegahan terjadinya fraud pada dasarnya adalah suatu usaha pengendalian dari sisi sumber daya manusianya. Kebijakan know your employee dalam perbankan sedikitnya mencakup 1) rekruitmen dengan menggunakan sistem serta prosedur yang efektif (employee screening), 2) mempertimbangkan resiko pada sistem seleksi dengan menyertakan kualifikasi yang sesuai, 3) berusaha lebih mengenal dan melakukan pemantauan terkait dengan perilaku, gaya hidup, serta bagaimana karakter karyawan.

BRI Cabang Gombong membawahi 20 BRI Unit pada wilayah kerjanya meliputi sebagian wilayah di Kabupaten Kebumen dan Banyumas. Dalam menjalankan fungsinya sebagai lembaga keuangan untuk menghimpun dana dari masyarakat berupa DPK serta menyalurkan kepada masyarakat yang berupa kredit. Pengelolaan terhadap DPK dan kredit dilakukan oleh Tenaga Marketing yang disebut sebagai Mantri. Mantri adalah karyawan marketing dan analisis mikro, bertugas mengurus bagian kredit mikro dan dana pihak ketiga (DPK) atau biasa juga disebut sebagai simpanan. Salah satu aturan yang diberlakukan yaitu
"Zero Tolerance" terhadap pelaku fraud, yaitu perusahaan tidak memberikan toleransi terhadap pelaku fraud sehingga harus dilakukan Pemutusan Hubungan Kerja (PHK). Hal ini dilakukan untuk memberikan pelajaran kepada pelaku serta pembelajaran kepada karyawan lainnya khususnya mantri.

Setiap tahun sejak tahun 2017 hingga tahun 2019 masih ditemukan adanya kasus fraud yang dilakukan oleh Mantri Bank BRI Kantor Cabang Gombong. Hal ini merupakan upaya pencegahan fraud di Bank BRI Kantor Cabang Gombong masih belum efektif. Pencegahan fraud menurut Karyono (2013) adalah berbagai usaha yang dilakukan untuk mencegah pelaku yang berpotensi melakukan tindakan fraud, mengurangi ruang gerak, serta memantau tindakan atau kegiatan-kegiatan yang memiliki resiko besar tarjadinya tindakan fraud.

Berdasarkan Fraud Triangle Theory, terjadinya fraud dikarenakan terdapat suatu kesempatan. Kesempatan melakukan fraud akan semakin luas ketika pengawasan atau pengendalian internal perusahaan tidak berjalan dengan efektif. Sunyoto (2014) berpendapat bahwa pengendalian internal adalah sistem dalam mengendalikan internal organisasi yang meliputi kebijakankebijakan, serta prosedur yang ditujukan untuk manajemen dalam memberikan suatu kepastian yang tepat, bahwa tujuan serta sasaran organisasi yang telah ditetapkan telah tercapai.

Dalam menjalankan kegiatan operasional, Bank BRI Cabang Gombong mempunyai berbagai kebijakan dan prosedur perusahaan. Salah satunya adalah pemberian wewenang dan tanggung jawab kepada mantri. Mantri diberikan berbagai macam kewenangan dan tanggung jawab seperti memprakarsai kredit dan melakukan penagihan setoran pinjaman. Aktivitas tersebut sangat rentan terhadap tindakan fraud. Selain pemberian wewenang prakarsa kredit dan penagihan 
setoran pinjaman, setiap mantri juga diberikan user ID dan password untuk mengakses berbagai informasi perusahaan serta melakukan berbagai transaksi baik financial maupun non financial. Setiap mantri juga membuat surat pernyataan untuk bertanggung jawab terhadap password masing - masing. Kerahasiaan password menjadi hal yang sangat penting, mengingat kebocoran password memungkinkan penyalahgunaan oleh orang yang tidak bertanggung jawab.

Selain adanya kesempatan, kondisi yang memungkinkan terjadinya fraud berdasarkan Fraud Triangle Theory adalah adanya tekanan (pressure). Lingkungan kerja merupakan suatu hal yang dapat mempengaruhi tekanan dalam diri seseorang, dan tekanan dapat diakibatkan oleh kompensasi dimana kompensasi merupakan salah satu faktor di dalam lingkungan kerja. Menurut Suarcaya, dkk. (2017), kesesuaian kompensasi merupakan kesesuaian serta kepuasan pekerja terhadap suatu usaha dari pekerja yang telah diberikan kepada organisasi berupa gaji yang diberikan perjam, ataupun secara periodik sebagai bayaran atas apa yang telah dilaksanakan oleh pekerja tersebut kepada organisasi.

Dalam melakukan pemberian kompensasi pada karyawan haruslah sesuai terhadap kontribusi karyawan yang telah dilakukan untuk organisasi. Sependapat dengan pernyataan Gibson, dkk. (1997) bahwa pemberian kompensasi dapat menciptakan kepuasan kerja dan motivasi karyawan, namun pemberian kompensasi haruslah sesuai, sehingga karyawan akan tergerak untuk melakukan yang terbaik bagi organisasi. Melalui pemberian kompensasi yang tepat maka karyawan akan merasa bahwa organisasi memperhatikan kesejahteraan mereka, sehingga diharapkan mempu meminimalkan terjadinya tindakan fraud seperti penipuan atau pencurian asetaset yang dilakukan oleh karyawan.
Kesesuiaan kompensasi yang diberikan perusahaan kepada mantri dalam upaya pencegahan fraud tidak akan maksimal apabila tidak didukung dengan budaya etis organisasi yang baik.

Simbolon (2017) mengemukakan bahwa budaya etis organisasi yaitu suatu nilai-nilai, norma ataupun anggapan yang menggambarkan bagaimana anggotaanggota organisasi berperilaku atau berinteraksi dengan sesama karyawan di dalam organisasi. Peran pemimpin sangat berpengaruh terhadap penerapan budaya etis organisasi yang merupakan bentuk peran yang konkret dan memberikan pengaruh bagi mantri agar berperilaku etis.

Sebagai model peran yang visible, sekalipun yang dilakukan pemimpin merupakan suatu tindakan kecurangan (fraud), namun budaya etis dari pemimpin merupakan suatu tindakan yang kerapkali dicontoh oleh karyawan. Karyawan akan merasa bahwa tindakannya sudah sesuai (rasionalization) karena sesuai dengan pemimpinnya. Sependapat dengan Cressey (1953), seseorang melakukan tindakan fraud dapat disebabkan oleh rasionalisasi atau pembenaran atas tindakan fraud yang dilakukan. Pelaku cenderung mencari alasan agar tindakannya tidak dinilai sebagai tindakan fraud.

Dalam prakteknya, peraturan dam komitmen terkait kode etik banyak dilanggar oleh mantri. Seperti pada proses prakarsa kredit, mantri masih memproses pengajuan kredit yang diajukan oleh anggota keluarga. Hal ini akan berpotensi menimbulkan benturan kepentingan (conflict of interest). Sikap yang dilakukan Mantri hendaknya tidak memanfaatkan jabatannya sehingga memberikan keluarganya, kerabatnya, atau pihak-pihak lainnya secara istimewa atas beban organisasi. Mantri yang terbukti melanggar kode etik selanjutnya akan diberlakukan sanksi/hukuman oleh Pemimpin Cabang berupa surat pembinaan. Namun hal ini 
tidak begitu menimbulkan efek jera karena hukuman ini relatif ringan.

Selain itu, Bank BRI menyediakan whistleblowing system sebagai sarana pelaporan terhadap tindakan - tidakan yang melanggar peraturan perusahaan seperti pelanggaran kode etik. Namun demikian, hal ini belum menjadi budaya dan seolah kurang mendapat perhatian, bahkan beberapa mantri tidak mengetahui perihal whistleblowing system. Ketidaktahuan ini sebagai akibat kurangnya sosialisasi yang dilakukan perusahaan khususnya pelanggaran kode etik dan prosedur pelaporannya.

Jika pencegahan fraud terhadap mantri di Bank BRI Cabang Gombong dinilai kurang efektif karena masih ditemukan adanya kasus fraud setiap tahunnya, maka perlu dilakukan evaluasi terhadap hal - hal yang diduga menyebabkan pencegahan fraud menjadi kurang efektif. Adapun evaluasi dapat dilakukan pada kondisi kondisi yang memungkinkan mantri melakukan tindakan fraud berdasarkan Fraud Triangle Theory (Cressey, 1953) yaitu kesempatan (opportunity) yang diproksikan dengan pengendalian internal, tekanan (pressure) yang diproksikan dengan kesesuaian kompensasi dan pembenaran (rasionalization) yang diproksikan dengan budaya etis organisasi. Dengan mengetahui dan melakukan perbaikan terhadap kondisi tersebut, maka diharapkan dapat mendukung upaya pencegahan fraud yang dilakukan.

\section{KAJIAN TEORI DAN PENGEMBANGAN HIPOTESIS}

\section{Pencegahan Fraud}

Fraud merupakan suatu dampak yang merugikan dari suatu tindakan disengaja dari karyawan yang melanggar ketentuanketentuan internal perusahaan seperti kebijakan, prosedur, atau sistem-sistem yang berlaku (Jaya, 2017). Pencegahan fraud menurut Karyono (2013:47) merupakan berbagai usaha yang dilakukan untuk mencegah pelaku yang berpotensi melakukan tindakan fraud, mengurangi ruang gerak, serta memantau tindakan atau kegiatan-kegiatan yang memiliki resiko besar tarjadinya tindakan fraud.

\section{Pengendalian Internal}

Sunyoto (2014), pengendalian internal yaitu suatu sistem dalam mengendalikan internal organisasi yang meliputi kebijakan-kebijakan, serta prosedur yang ditujukan untuk manajemen dalam memberikan suatu kejelasan yang menyatakan tujuan serta sasaran organisasi telah tercapai.

\section{Kesesuaian kompensasi}

Kesesuaian kompensasi yaitu kesesuaian serta kepuasan pekerja terhadap suatu usaha dari pekerja yang telah diberikan kepada organisasi berupa gaji yang diberikan perjam, ataupun secara periodik sebagai bayaran atas apa yang telah dilaksanakan oleh pekerja tersebut kepada organisasi (Suarcaya, dkk., 2017).

\section{Budaya Etis Organisasi}

Simbolon (2017) mengemukakan bahwa budaya etis organisasi berarti nilainilai, norma ataupun anggapan yang menggambarkan bagaimana anggotaanggota organisasi berperilaku atau berinteraksi dengan sesama karyawan di dalam organisasi. Peran pemimpin sangat berpengaruh terhadap penerapan budaya etis organisasi yang merupakan bentuk peran yang konkret dan memberikan pengaruh bagi mantri agar berperilaku etis.

\section{Pengaruh Pengendalian Internal Terhadap Pencegahan fraud}

Berdasarkan Fraud Triangle Theory, terjadinya fraud dikarenakan terdapat suatu kesempatan. Kesempatan melakukan fraud akan semakin luas ketika pengawasan atau 
pengendalian internal perusahaan tidak berjalan dengan efektif. Hal tersebut didukung oleh temuan Nugraha dan Bayunitri (2020) dan Ananda, dkk. (2016) yang menyatakan pengendalian internal berpengaruh signifikan terhadap pencegahan fraud. Artinya, pengendalian internal yang semakin baik pada suatu perusahaan maka pencegahan fraud juga akan semakin baik/meningkat. Pengendalian internal yang baik akan memperkecil kecenderungan fraud.

H1 : Terdapat berpengaruh positif pengendalian internal terhadap pencegahan fraud pada Mantri Bank BRI Cabang Gombong.

\section{Pengaruh Pemberian Kompensasi Terhadap Pencegahan Fraud}

Kondisi yang memungkinkan terjadinya fraud berdasarkan Fraud Triangle Theory adalah adanya tekanan (pressure). Lingkungan kerja merupakan suatu hal yang dapat mempengaruhi tekanan dalam diri seseorang, dan tekanan dapat ditimbulkan oleh pemberian kompensasi dimana kompensasi adalah salah satu faktor dalam lingkungan kerja. Pemberian kompensasi dapat menciptakan kepuasan kerja dan motivasi karyawan, namun pemberian kompensasi haruslah sesuai sehingga karyawan akan tergerak untuk melakukan yang terbaik demi organisasi/perusahaan (Gibson, dkk., 1997). Melalui pemberian kompensasi yang tepat maka karyawan akan merasa bahwa organisasi memperhatikan kesejahteraan mereka, sehingga diharapkan mempu meminimalkan terjadinya tindakan fraud seperti penipuan atau pencurian aset-aset yang dilakukan oleh karyawan. Hal ini sesuai dengan temuan Purnamasari (2015), kesesuaian kompensasi berpengaruh terhadap pencegahan fraud. Artinya bahwa pemberian kompensasi yang baik dan sesuai, maka akan semakin baik pula pencegahan fraud di suatu organisasi.
H2 : Terdapat berpengaruh positif kesesuaian kompensasi terhadap pencegahan fraud pada Mantri Bank BRI Cabang Gombong.

\section{Pengaruh Budaya Etis Organisasi Terhadap Pencegahan Fraud}

Hal yang sangat penting kedudukannya di dalam suatu organisasi yaitu usaha menyesuaikan pemikiran diantara orang yang akan dipengaruhi perilakunya dengan orang yang perilakunya akan mempengaruhi (Megawati, 2018). Dalam kasus ini, kedekatakan antara atasan dan bawahannya sangat diperlukan. Selain itu, adanya komunikasi yang baik dan jelas juga sangat dibutuhkan. Sebagai model peran yang visible, sekalipun yang dilakukan pemimpin merupakan suatu tindakan kecurangan (fraud), namun budaya etis dari pemimpin merupakan suatu tindakan yang kerapkali dicontoh oleh karyawan. Karyawan akan merasa bahwa tindakannya sudah sesuai (rasionalization) karena sesuai dengan pemimpinnya. Sependapat dengan Cressey (1953), seseorang melakukan tindakan fraud dapat disebabkan adanya rasionalisasi atau pembenaran atas tindakan fraud yang dilakukan. Pelaku cenderung mencari alasan agar tindakannya tidak dinilai sebagai tindakan fraud. Hal tersebut didukung oleh temuan Bachtiar dan Elliyana (2020) menemukan bahwa semakin tingginya budaya etis suatu perusahaan/organisasi maka pencegahan tindakan fraud juga akan semakin baik, dan Fajrin (2017) dengan temuannya yaitu budaya etis organisasi memiliki pengaruh yang positif terhadap pencegahan fraud.

H3 : Terdapat pengaruh positif budaya etis organisasi terhadap pencegahan fraud pada Mantri Bank BRI Cabang Gombong. 
Pengaruh Pengendalian Internal, Pemberian Kompensasi, dan Budaya Etis Organisasi Terhadap Penvegahan Fraud

Upaya pencegahan merupakan langkah awal sebagai suatu cara dalam mengantisipasi terjadinya tindakan fraud meliputi fraud awaresess, mengidentifikasi adanya kerawanan, dan mengenali karyawan. Mengenali karyawan (know your employee) merupakan tindakan dalam mencegahan terjadinya fraud pada dasarnya adalah suatu usaha pengendalian dari sisi sumber daya manusianya. Cressey (1953) mengembangkan sebuah teori yang dikenal dengan Teori Segitiga Fraud (Fraud Triangle Theory) menemukan bahwa fraud terjadi pada tiga kondisi yaitu adanya kesempatan untuk melakukan tindakan kecurangan (opportunity), adanya tekanan pada diri orang tersebut (pressure), dan rasionalisasi (rasionalization). Berdasarkan Fraud Triangle Theory, Kesempatan melakukan fraud akan semakin luas ketika pengawasan atau pengendalian internal perusahaan tidak berjalan dengan efektif. Selain adanya kesempatan, kondisi yang memungkinkan terjadinya fraud berdasarkan Fraud Triangle Theory adalah adanya tekanan (pressure). Lingkungan kerja merupakan suatu hal yang dapat mempengaruhi tekanan dalam diri seseorang, dan takanan ini dapat ditimbulkan oleh kompensasi dimana kompensasi merupakan salah satu faktor dari lingkungan kerja. Kesesuiaan kompensasi yang diberikan perusahaan kepada karyawan dalam upaya pencegahan fraud tidak akan maksimal apabila tidak didukung dengan budaya etis organisasi yang baik.

H4: Terdapat pengaruh positif dan signifikan pengendalian internal, kesesuaian kompensasi dan budaya etis organisasi secara simultan terhadap pencegahan fraud pada Mantri Bank BRI Cabang Gombong.

Dari hipotesis di atas maka terbentuklah model empiris yaitu sebagai berikut:

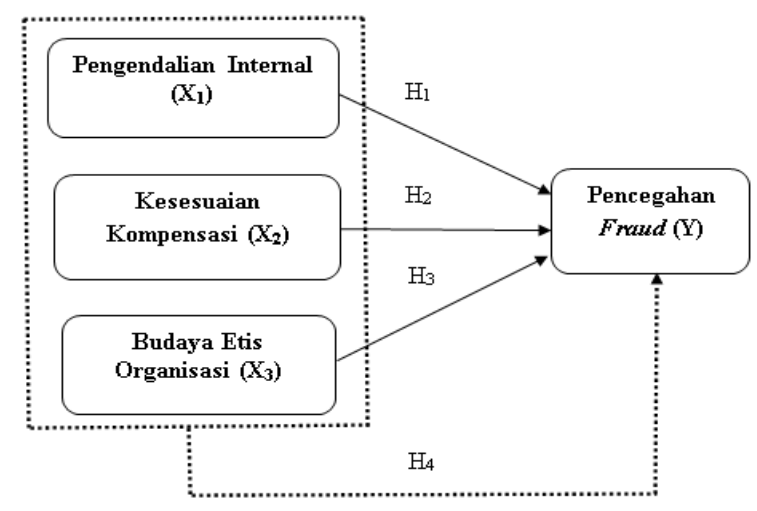

Gambar 1. Model Empiris Penelitian

\section{METODOLOGI PENELITIAN}

$\begin{array}{ccc}\text { Objek } & \text { penelitian } & \text { ini adalah } \\ \text { pengendalian } & \text { internal, } & \text { kesesuaian }\end{array}$ kompensasi dan budaya etis organisasi (independent variable) dan pencegahan fraud yang merupakan variabel terikat (dependent variable). Subjek penelitian ini yaitu Mantri Bank BRI Cabang Gombong dengan berstatus karyawan tetap dan kriteria telah bekerja minimal selama satu tahun. Populasi penelitian yaitu Mantri Bank BRI Cabang Gombong sebanyak 96 mantri. Penentuan sampel dengan sampel jenuh. Analisis data dengan analisis deskriptif dan verifikatif. Adapun alat analisis statistik menggunakan aplikasi SPSS 22 for windows.

\section{HASIL DAN PEMBAHASAN}

\section{Uji Validitas dan Reliabilitas}

Hasil pada semua instrument pada penelitian ini dinyatakan valid ( $\mathrm{r}$ hitung > $r$ tabel), dan hasil uji reliabilitas dalam penelitian ini dinyatakan reliable (nilai Alpha $>0,60$ ). 


\section{Uji Asumsi Klasik}

\section{Uji Normalitas}

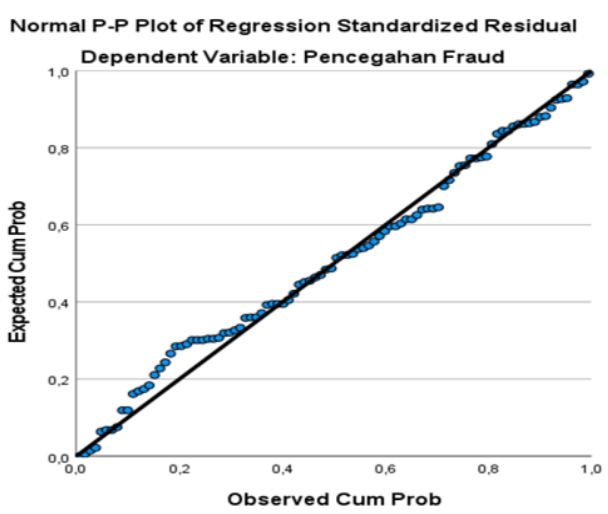

Gambar 2. Hasil Uji Normalitas

Sumber : Hasil Output SPSS, 2020

Dari hasil uji normalitas dapat dijelaskan bahwa titik-titik mengikuti dan mendekati garis diagonalnya, sehingga asumsi normalitas dalam penelitian-ini terpenuhi.

\section{Uji Multikolinearitas}

Tabel 1. Hasil Uji Multikolinearitas

\begin{tabular}{|l|c|c|}
\hline \multirow{2}{*}{\multicolumn{1}{|c|}{ Model }} & \multicolumn{2}{c|}{ Collinearity Statistics } \\
\cline { 2 - 3 } & Tolerance & VIF \\
\hline Pengendalian Internal & 0,599 & 1,669 \\
\hline Kesesuaian Kompensasi & 0,592 & 1,691 \\
\hline Budaya Etis Organisasi & 0,840 & 1,191 \\
\hline
\end{tabular}

Sumber : Hasil Output SPSS, 2020

Berdasarkan hasil tersebut dapat dijelaskan nilai VIF dari setiap variabel bebas $<10$ serta tolerance $>0,1$, sehingga dalam penelitian ini tidak terjadimultikolinearitas dan model-regresi dapat digunakan.

\section{Uji Heteroskesdastisitas}

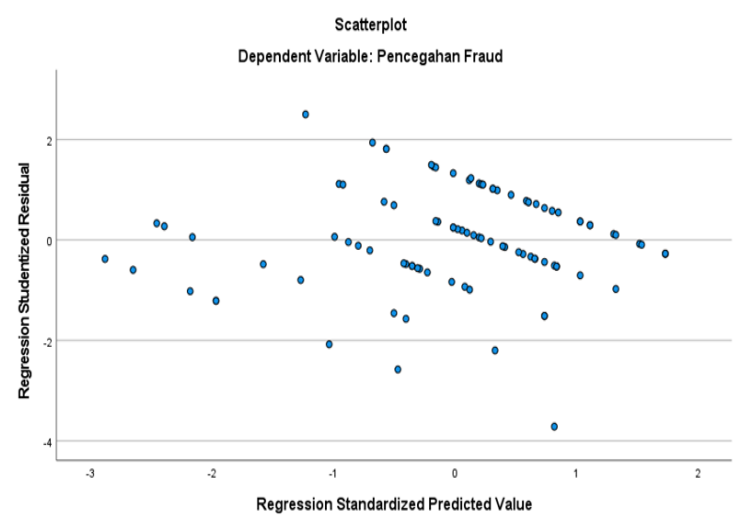

Gambar 3. Hasil Uji Heteroskesdastisitas Sumber : Hasil Output SPSS, 2020
Dari hasil tersebut dapat dijelaskan plot tidak terdapat suatu pola yang jelas, sehingga dalam-penelitian ini tidak terjadi masalah heteroskedastisitas.

\section{Analisis Regresi Linear Berganda \\ Berikut hasil uji regresi dalam penelitian ini.}

Tabel 2. Hasil Uji Regresi Linear Berganda

\begin{tabular}{|c|l|c|c|}
\hline \multirow{2}{*}{\multicolumn{2}{|c|}{ Model }} & \multicolumn{2}{c|}{$\begin{array}{c}\text { Unstandarized } \\
\text { Coefficient }\end{array}$} \\
\cline { 3 - 4 } \multicolumn{2}{|c|}{} & B & Std. Error \\
\hline 1 & (Constant) & 3,698 & 1,268 \\
\hline & Pengendalian Internal &, 249 &, 078 \\
\hline & Kesesuaian Kompensasi &, 165 &, 063 \\
\hline & Budaya Etis Organisasi &, 180 &, 057 \\
\hline
\end{tabular}

Sumber : Hasil Output SPSS, 2020

Model regresi yang terbentuk yaitu:

$Y=3,698+0,249 X_{1}+0,165 X_{2}+0,180 X_{3}+$ $\boldsymbol{\varepsilon}$

1. Konstanta memiliki nilai sebesar 3,698 , artinya jika variabel pengendalian internal (X1), kesesuaian kompensasi (X2), dan budaya etis organisasi (X3) memiliki nilai sama dengan nol, maka variabel dependen (pencegahan fraud) memiliki nilai konstanta sebesar 3,698.

2. Setiap penambahan satu-satuan pada variabel pengendalian internal (X1) maka variabel pencegahan fraud akan meningkat sebesar 0,249 dengan asumsi variabel lain tetap.

3. Setiap penambahan satu-satuan pada variabel kesesuaian kompensasi (X2) maka variabel pencegahan fraud akan meningkat sebesar 0,165 dengan asumsi variabel lain tetap.

4. Setiap penambahan satu-satuan pada variabel budaya etis organisasi (X3) maka variabel pencegahan fraud akan meningkat sebesar 0,180 dengan asumsi variabel lain tetap.

\section{Uji Hipotesis \\ Parsial (Uji t)}

Tabel 3. Hasil Uji Hipotesis Parsial (Uji t)

\begin{tabular}{|c|c|c|c|}
\hline Variabel Independen & thitung & ttabel & Sig \\
\hline Pengendalian Internal & 3,210 & 1,661 &, 002 \\
\hline
\end{tabular}




\begin{tabular}{|c|c|c|c|}
\hline Kesesuaian Kompensasi & 2,628 & 1,661 &, 010 \\
\hline Budaya Etis Organisasi & 3,146 & 1,661 &, 002 \\
\hline
\end{tabular}

Sumber : Hasil Output SPSS, 2020

1. Pengendalian internal (X1) memiliki nilai signifikan sebesar $0,002<0,05$ dan $t_{\text {hitung }}>t_{\text {tabel }}(3,210>1,661)$. Hasil tersebut dapat dijelaskan bahwa terdapat pengaruh positif dan signifikan variabel pengendalian internal (X1) terhadap pencegahan fraud, sehingga $\mathrm{H} 1$ diterima.

2. Kesesuaian kompensasi (X2) memiliki nilai signifikan sebesar $0,010<0,05$ dan $t_{\text {hitung }}>t_{\text {tabel }}(3,628>1,661)$. Hasil tersebut dapat dijelaskan bahwa terdapat pengaruh positif dan signifikan variabel kesesuaian kompensasi (X2) terhadap pencegahan fraud, sehingga $\mathrm{H} 2$ diterima.

3. Budaya etis organisasi (X3) memiliki nilai signifikan sebesar 0,002< 0,05 dan $t_{\text {hitung }}>t_{\text {tabel }}(3,146>1,661)$. Hasil tersebut dapat dijelaskan bahwa terdapat pengaruh simultan budaya etis organisasi (X3) terhadap pencegahan fraud, sehingga $\mathrm{H} 1$ diterima.

\section{Uji Hipotesis Simultan (Uji F)}

Tabel 4. Hasil Uji Simultan (Uji F)

\begin{tabular}{|c|l|c|c|}
\hline \multicolumn{2}{|c|}{ Model } & F & Sig \\
\hline 1 & $\begin{array}{l}\text { Regression } \\
\text { Residual } \\
\text { Total }\end{array}$ & 25,617 & $0,000^{\mathrm{b}}$ \\
\hline
\end{tabular}

Sumber : Hasil Output SPSS, 2020

Berdasarkan hasil tersebut dapat jelaskan nilai signifikansi kurang dari 0,05 $(0,000<0,005), F_{\text {hitung }}>F_{\text {tabel }}(25,617>$ 2,70), sehingga $\mathrm{H} 4$ diterima dengan kata lain terdapat pengaruh simultan pengendalian internal, kesesuaian kompensasi dan budaya etis organisasi terhadap pencegahan fraud.

\section{Koefisien Determinasi}

Tabel 5. Koefisien Determinasi

\begin{tabular}{|c|c|c|c|c|}
\hline Model & $\mathbf{R}$ & $\begin{array}{c}\mathbf{R} \\
\text { Square }\end{array}$ & $\begin{array}{c}\text { Adjusted } \\
\text { R Square }\end{array}$ & $\begin{array}{c}\text { Std. Error } \\
\text { of the }\end{array}$ \\
\hline 1 &, $674^{\mathrm{a}}$ &, 455 &, 437 &, 944 \\
\hline
\end{tabular}

Sumber : Hasil Output SPSS, 2020

Variabel pencegahan fraud dapat dijelaskan oleh variabel pengendalian internal (X1), kesesuaian kompensasi (X2), dan budaya etis organisasi (X3) dalam model penelitian ini sebesar $43,7 \%$, dan sisanya sebesar $56,3 \%$ dijelaskan oleh variabel di luar penelitian ini.

\section{Pembahasan}

\section{Pengaruh Pengendalian Internal Terhadap Pencegahan Fraud}

Dari hasil kuesioner responden, pengendalian internal di Bank BRI Cabang Gombong secara umum di golongkan dalam kategori sangat baik. Namun, terdapat satu pernyataan dengan skor terendah yaitu pernyataan yang mewakili indikator sistem informasi. Hal ini berarti bahwa pengendalian internal terhadap sistem informasi, khususnya kelengkapan berkas belum maksimal sehingga perlu adanya peningkatan evaluasi dan pemantaun khusus terhadap kelengkapan berkas berkas kegiatan operasional. Berdasarkan hasil uji hipotesis (uji t) diperoleh bahwa terdapat pengaruh positif dan signifikan pengendalian internal terhadap pencegahan fraud dan $\mathrm{H}_{1}$ diterima. Artinya, jika pengendalian internal di suatu organisasi semakin baik maka pencegahan fraud juga akan semakin baik pula.

\section{Pengaruh Kesesuaian Kompensasi Terhadap Pencegahan Fraud}

Hasil kuesioner responden diperoleh, kesesuaian kompensasi dengan kontribusi yang diberikan mantri kepada Bank BRI Cabang Gombong secara umum termasuk kategori sangat baik. Namun, terdapat satu pernyataan dengan skor terendah yaitu pernyataan yang mewakili indikator kompensasi interpersonal. Hal ini mengindikasikan masih adanya Mantri Bank BRI Cabang 
Gombong yang merasa tidak diakui hasil kerjanya. Jika dibiarkan terlalu lama, hal ini dapat menimbulkan ketidakpuasan dan pada akhirnya berpotensi menimbulkan tindakan fraud. Hasil uji hipotesis (uji t) diperoleh terdapat pengaruh positif dan signifikan kesesuaian kompensasi terhadap pencegahan fraud, sehingga $\mathrm{H}_{2}$ diterima. Artinya, kompensasi yang semakin baik dan sesuai maka pencegahan fraud juga akan semakin baik atau semakin tinggi dan berlaku juga sebaliknya.

\section{Pengaruh Budaya Etis Organisasi Terhadap Pencegahan Fraud}

Hasil kuesioner responden dapat dijelaskan, budaya etis organisasi di Bank BRI Cabang Gombong secara umum dalam kategori sangat baik. Namun demikian, terdapat satu pernyataan dengan skor terendah yaitu pernyataan yang mewakili indikator komunikasi harapan-harapan etis. Hal ini menunjukkan bahwa adanya kode etik di Bank BRI Cabang Gombong masih belum menyampaikan informasi sepenuhnya kepada mantri untuk diimplentasikan dalam kegiatan operasional perusahaan. Berdasarkan hasil uji hipotesis diperoleh hasil terdapat pengaruh positif dan signifikan budaya etis

organisasi terhadap pencegahan fraud dan $\mathrm{H}_{3}$ diterima. Artinya, budaya etis organisasi yang semakin baik, maka pencegahan fraud di suatu organisasi juga akan semakin baik.

\section{KESIMPULAN}

Adapun kesimpulan dari penelitian ini adalah sebagai berikut:

1. Pengendalian internal berpengaruh positif dan signifikan terhadap pencegahan fraud. Hal ini menunjukkan bahwa Semakin baik pengendalian internal di suatu organisasi maka pencegahan fraud di dalam organisasi tersebut juga akan meningkat.

2. Kesesuaian kompensasi berpengaruh positif dan signifikan terhadap pencegahan fraud. Hal ini menunjukkan bahwa Artinya, apabila kesesuaian kompensasi semakin baik, maka pencegahan fraud pada organisasi juga akan semakin baik.

3. Budaya etis organisasi berpengaruh positif dan signifikan terhadap pencegahan fraud. Hal ini menunjukkan bahwa Artinya, apabila budaya etis organisasi semakin baik maka pencegahan fraud juga akan meningkat.

4. Pengendalian internal, kesesuaian kompensasi dan budaya etis organisasi secara simultan berpengaruh positif dan signifikan terhadap pencegahan fraud. Artinya, apabila ketiga variabel tersebut diterapkan secara bersama-sama maka akan mampu meningkatkan pencegahan terjadinya fraud di Bank BRI Cabang Gombong.

\section{SARAN}

1. Hasil penelitian ini dapat digunakan sebagai bahan pertimbangan bagi manajemen Bank BRI Cabang Gombong agar lebih meningkatkan pengendalian internal dengan prioritas utama pada informasi kegiatan operasional di perusahaan yang berupa kelengkapan berkas berkas operasional khususnya dokumen kredit. Dengan adanya dokumentasi kredit yang lengkap, informasi kegiatan operasional perusahaan akan semakin jelas sehingga akan memperkecil 
kesempatan untuk melakukan tindakan fraud.

2. Manajemen PT. Bank Rakyat Indonesia (Persero) Tbk Kantor Cabang Gombong agar lebih memperhatikan

kesesuaian kompensasi yang diterima mantri dengan tuntutan yang diberikan perusahaan. Sebaiknya perusahaan tidak hanya fokus pada kompensasi keuangan saja tetapi juga perlu untuk memperhatikan kompensasi interpersonal yang berupa pengakuan terhadap hasil kerja mantri. Dengan adanya pengakuan terhadap hasil kerja, maka mantri akan cenderung merasa dihargai dan tercipta kepuasan kerja yang pada akhirnya mantri cenderung tidak akan melakukan tindakan fraud.

3. Manajemen PT. Bank Rakyat Indonesia (Persero) Tbk Kantor Cabang Gombong agar lebih memperhatikan penerapan budaya etis organisasi dalam kegiatan operasional perusahaan yang masih tergolong rendah. Manajemen dapat memanfaatkan sharing session pada saat doa pagi untuk menciptakan dan mengkomunikasikan kode etik organisasi. Jika budaya etis organisasi telah melekat pada setiap aktivitas mantri, maka kemungkinan mantri untuk melakukan tindakan fraud akan cenderung rendah.

\section{DAFTAR PUSTAKA}

Albrecht, W.S. 2012. Fraud Examination. South Western: Cengage Learning. Amrizal. 2004. Pencegahan dan Pendeteksian Kecurangan oleh Auditor Internal. Jakarta : BPKP.

Ananda, K.P., Purnamasari, P., Gunawan, H. "Pengaruh Pengendalian Internal Terhadap Pencegahan Fraud".
Seminar Penelitian Sivitas Akademika Unisba. Diambil dari http://karyailmiah.unisba.ac.id/inde x.php/akuntansi/article/view/5115 diakses pada 20 November 2020.

Anatan, L. dan Ellitan, L. 2009. Manajemen Sumber Daya Manusia Dalam Bisnis Modern. Bandung : Alfabeta.

Annual Report BRI Tahun 2019. [Versi elektronik]. Diambil dari https://bri.co.id/report diakses pada 11 Oktober 2020.

Ardianingsih, A. 2017. Audit Laporan Keuangan. Pekalongan : PT Bumi Aksara.

Arens, A.A., dkk. 2012. Jasa Audit dan Assurance. Edisi 14. Jakarta : Salemba Empat.

Arikunto, Suharsimi. 2002. Metodologi Penelitian. Jakarta: Penerbit PT. Rineka Cipta.

Bachtiar, I.H. dan Elliyana, E. "Determinan Upaya Pencegahan Fraud Pemerintah Desa". Imanesi : Jurnal Ekonomi, Manajemen dan Akuntansi Islam, Vol.5. Diambil dari https://jurnal.fordebi.or.id/index.ph $\mathrm{p} /$ home/article/view/104 diakses tanggal 24 Oktober 2020.

Cendekia, C., Syahza, A., Trisnawati, F. "Pengaruh Efektivitas Pengendalian Internal dan Kesesuaian Kompensasi Terhadap Pencegahan Kecurangan (Fraud) Pada PDAM Tirta Siak Pekanbaru". Jurnal Online Mahasiswa Fakultas Keguruan dan Ilmu Pendidikan. Diambil dari https://jom.unri.ac.id/index.php/JO MFKIP/article/view/10812 diakses pada 20 November 2020.

COSO. 1992. "Internal Control Integrated Frame Work". Committee of Sponsoring Organizations of The Treadway Commision, Vol.2. Diambil dari

https://www.coso.org/Pages/guida nce.aspx diakses pada 10 Oktober 2020.

Cressey, D. 1953. “Other People's Money : a Study in the Social Psychology of Embezzlement". American Journal of Sociology, Vol.59. Diambil dari https://www.journals.uchicago.edu 
Ldoi/abs/10.1086/22147 diakses tanggal 10 Oktober 2020.

Fajrin, R.F. 2017. Pengaruh Pengendalian Internal, Kepuasan Kerja, Moralitas Manajemen dan Budaya Etis Organisasi Terhadap Pencegahan Kecurangan. Skripsi S1 (Tidak dipublikasikan). Bandung : Fakultas Ekonomi Universitas Pasundan.

Ghozali, Imam. 2009. Aplikasi Analisis Multivariate dengan Program SPSS. Semarang : UNDIP.

Gibson, J., L.J.M., Ivancevich, James H. Donnely, Jr (terj.). 1997. Organizations. Cetakan Keempat. Jakarta : PT. Gelora Aksara Pratama.

Handoko, T. Hani. 2001. Manajemen Personalia dan Sumber Daya Manusia. Yogyakarta : Penerbit Andi.

Hasibuan, Malayu. 2009. Manajemen Sumber Daya Manusia. Edisi Revisi. Jakarta : Bumi Aksara.

Jaya, A. 2017. "Pengaruh Pengendalian Internal dan Komitmen Pimpinan Terhadap Kecenderungan Kecurangan Akuntansi pada Pemerintah Kabupaten Musi Rawas". Jimat : Jurnal Ilmiah Mahasiswa Akuntansi, Vol.7. 1-14. Diambil dari https://stie-mdp.ac.id diakses tanggal 10 Oktober 2020.

Jimmy, C. H. R. 2014. Manajemen Sumber Daya Manusia. Jakarta : Gramedia Widiasarana Indonesia.

Jusup, A.H. 2014. Auditing (Pengauditan Berbasis ISA). Yogyakarta : Pusat Penerbitan STIE YKPN.

Kartono, Kartini. 2003. Patologi Sosial. Jakarta : Rajawali Pres.

Karyono. 2013. Forensic Fraud. Yogyakarta : CV. Andi.

Kuncoro, Mudrajad. 2009. Metode Riset Untuk Bisnis \& Ekonomi. Jakarta : Erlangga

Mangkunegara, A.P. 2001. Manajemen Sumber Daya Perusahaan. Bandung : PT. Remaja Rosdakarya.

Martoyo, S. 1994. Manajemen Sumber Daya Manusia.Yogyakarta : BPFE.

Mayangsari dan Wandanarum. 2013. Auditing Pendekatan Sektor Publik dan Privat. Jakarta : Media Bangsa.

Megawati, M.H. 2018. Pengaruh Penegndalian Internal, Budaya Etis
Organisasi dan Gaya Kepemimpinan Terhadap Fraud Pada Universitas Swasta di Bandar Lampung. Tesis (Tidak dipublikasikan). Bandar Lampung : Universitas Bandar Lampung.

Mustika, D., Hastuti, S., Hariningsih, S. 2016. "Analisis Faktor - Faktor yang Mempengaruhi Kecenderungan Kecurangan (Fraud)". Simposium Nasional Akuntansi XIX". Diambil dari

http://lib.ibs.ac.id/materi/Prosiding L-

SNA\%20XIX\%20(19)\%20Lampung \%202016/makalah/006.pdf diakses pada 20 November 2020.

Narimawati, Umi. 2007. Riset Manajemen Sumber Daya Manusia. Jakarta : Agung Media.

Nazir, M. 1988. Metode Penelitian. Jakarta : Ghalia Indonesia.

Nugraha, R. dan Bayunitri, B.I. 2020. "The Influence of Internal Control on Fraud Prevention (Case Study at Bank BRI of Cimahi City)". International Journal of Financial, Accounting and Management (IJFAM), Vol 2. Diambil dari https://scholar.google.co.id/citation s?user=ZQ8035MAAAAJ\&hl=en diakses pada 20 November 2020.

Peraturan Otoritas Jasa Keuangan Nomor 30/POJK.03/2019 tentang Penerapan Strategi Anti Fraud Bagi Bank Umum. [Versi Elektronik]. Diambil dari https://ojk.go.id/id/regulasi diakses pada 10 Oktober 2020.

Pristiyanti, I.R. 2012. Persepsi Pegawai Instansi Pemerintah Mengenai Faktor-Faktor yang Mempengaruhi Fraud di Sektor Pemerintahan. Skripsi (Tidak dipublikasikan). Semarang : Fakultas Ekonomi UNNES.

Purnamasari, D. 2015. Pengaruh Penerapan Pengendalian Internal, Kesesuaian Kompensasi dan Moralitas Manajemen Terhadap Pencegahan Fraud. Skripsi S1 (Tidak dipublikasikan). Bandung : Fakultas Ekonomi Universitas Pasundan.

Purwitasari, A. 2013. Pengaruh Pengendalian Internal dan 
Komitmen Organisasi dalam

Pencegahan Fraud Pengadaan

Barang (Studi pada 5 Rumah Sakit di

Bandung). Skripsi (Tidak

dipublikasikan). Bandung : Fakultas

Ekonomi Universitas Widyatama.

Robbins, S. P. dan Judge, T. A. 2008. Perilaku Organisasi. Edisi 12. Jakarta : Salemba Empat.

Sawyer, P.S. 2005. Sawyer's Internal Auditing. Jakarta : Salemba Empat.

Simbolon, David K. 2017. Analisis Faktorfaktor yang Mempengaruhi Fraud di Lingkungan Instansi Pemerintahan Kabupaten Dairi. Tesis Magister (Tidak dipublikasikan). Medan : Universitas Sumatera Utara.

Soleman, R. 2013. "Pengaruh Pengendalian Internal dan Good Corporate Governance Terhadap Pencegahan Fraud". JAAI : Jurnal Akuntansi dan Auditing Indonesia, Vol.17. Diambil dari

https://journal.uii.ac.id/JAAI/article $\angle$ view/3771 diakses pada 16 Oktober 2020.

Suarcaya, I.B.K., Prayudi, M.A., Herawati, N.T. 2017. "Pengaruh Kesesuaian Kompensasi, Pengendalian Internal dan Perilaku Tidak Etis Terhadap Kecenderungan (Fraud) (Studi Kasus pada Persepsi Pegawai Koperasi (KSP) Simpan Pinjam Kabupaten Buleleng". Jurnal Ilmiah Mahasiswa Akuntansi Undiksha, Vol.8. Diambil dari https://ejournalundiksha.ac.id/index.php/S1ak/arti cle/view/14598 diakses pada 24 Oktober 2020.

Sugiyono. 2009. Metode Penelitian Bisnis. Bandung : Alfabeta.

2010. Metode Penelitian Pendidikan Pendekatan Kuantitatif, Kualitatif dan R\&D. Bandung: Alfabeta 2012. Metode Penelitian Bisnis. Bandung : Alfabeta.

Sujarweni, V. Wiratna. 2019. Metodologi Penelitian Bisnis dan Ekonomi. Yogyakarta : Pustaka Baru Press.

Sunyoto, D. 2014. Auditing Pemeriksaan Akuntansi. Yogyakarta : CAPS (Center of Academic Publishing Service).
Survey Fraud Indonesia 2016. [Versi elektronik]. Diambil dari http://acfe-indonesia.or.id/wpcontent/uploads/2017/07/SURVAIFRAUD-INDONE-SIA-2016.pdf diakses tanggal 09 Oktober 2020.

Survey Fraud Indonesia 2019. [Versi elektronik]. Diambil dari https://acfe-indonesia.or.id/surveifraud-indonesia/ diakses pada 11 Oktober 2020.

Sutrisno, H. 2004. Metodologi Research. Jilid 2. Yogyakarta : Andi Offset.

Tuanakotta, T.M. 2007. Akuntansi Forensik dan Audit Investigatif. Jakarta : Lembaga Penerbit Fakultas Ekonomi Universitas Indonesia. 2013. Audit berbasis ISA(International Standards on Auditing). Jakarta : Salemba Empat.

Tunggal, A.W. 2009. Akuntansi Manajemen. Jakarta : Harvindo.

Tunggal, A.W., Saputra, K.A.K., Vijaya, D.P. 2014. Metodologi Peneltian Bisnis. Yogyakarta : Graha Ilmu.

Undang - Undang Republik Indonesia Nomor 20 Tahun 2001 tentang Perubahan Atas Undang - Undang Nomor 31 Tahun 1999 tentang Pemberantasan Tindak Pidana Korupsi. [Versi elektronik]. Diambil dari

https://www.hukumonline.com/pus atdata/detail/339/undangundang-

nomor-20-tahun-2001\# diakses tanggal 10 Oktober 2020.

Wardana, I.G.A.K., Sujana, E., Wahyuni, M.A. "Pengaruh Pengendalian Internal, Whistleblowing System dan Moralitas Aparat Terhadap Pencegahan Fraud pada Dinas Pekerjaan Umum Kabupaten Buleleng". Jurnal Ilmiah Mahasiswa Akuntansi Undiksha, Vol.8. Diambil dari

https://ejournal.undiksha.ac.id/inde x.php/S1ak/article/view/12161 diakses tanggal 26 Oktober 2020.

Widodo, S.E. 2015. Manajemen Pengembangan Sumber Daya Manusia. Yogyakarta : Pustaka Pelajar. 